\title{
AVALIAÇÃO DO POTENCIAL BIOTECNOLÓGICO PARA O TRATAMENTO DE UM MINÉRIO DE OURO DE UMA MINA DO ESTADO DO AMAPÁ
}

Luana Cardoso Grangeiro ' Denise Bevilaqua ${ }^{2}$ Kleber Bittencourt Oliveira ${ }^{3}$ Mauricio Cesar Palmieri ${ }^{4}$ Emanuel Negrão Macêdo ${ }^{5}$

\section{Resumo}

O presente trabalho avaliou a melhor rota biotecnológica para o pré-tratamento de um minério aurífero e o efeito destes tratamentos na avaliação do consumo de cianeto durante a cianetação. Para este fim, testes de bioxidação foram conduzidos em escala de laboratório utilizando um minério aurífero $(90 \mathrm{~g} / \mathrm{ton} \mathrm{Au})$ proveniente de uma mina situada no Estado do Amapá, Brasil. As culturas bacterianas utilizadas nos testes biológicos foram Acidithiobacillus ferrooxidans, linhagem LR e Acidithiobacillus thiooxidans, linhagem FGOI. Os produtos do processo de bioxidação foram submetidos a ensaios de cianetação para testes de avaliação de consumo de cianeto e recuperação de ouro. Os estudos experimentais realizados mostraram que após $24 \mathrm{~h}$ de cianetação da amostra mineral sem tratamento a recuperação de ouro foi de $93 \%$ ( $32 \mathrm{mg} / \mathrm{L}$ ) com o consumo de $\mathrm{NaCN}$ de 2,86 kg.t-1 ${ }^{-1}$, enquanto a melhor extração entre as amostras bioxidadas foi a do biorreator R2 de condição oxidante com $87 \%$ (30 mg/L) de ouro, e com consumo de 2,64 kg.t $\mathrm{t}^{-1}$ de NaCN. Os resultados obtidos mostraram a viabilidade da técnica de bioxidação antes da cianetação para a redução no consumo de cianeto.

Palavras-chave: Minério aurífero; Acidithiobacillus; Bioxidação; Cianetação.

\section{EVALUATION OF BIOTECNOLOGICAL POTENCIAL FOR TREATING OF A ONE GOLD ORE FROM A MINE OF AMAPÁ STATE}

\begin{abstract}
The aim of this work was to study the best biotechnology route for the pretreatment of the gold ore in order to reduce cyanide consumption during the conventional cyanidation and increasing the gold recovery. For this purpose, biological tests have been investigated at laboratory scale on a gold ore sample coming from Estado do Amapá, Brazil ( $90 \mathrm{~g} /$ ton). Bacterial cultures utilized in the biological tests of 20 days consisted of Acidithiobacillus ferrooxidans LR and Acidithiobacillus thiooxidans FGOI. The biooxidated samples were submitted to cyanidation tests for gold recovery and tests of consumption of cyanide. Experimental studies demonstrated that after $24 \mathrm{~h}$ leaching time by direct cyanidation, the gold recovery was $93 \%(32 \mathrm{mg} / \mathrm{L})$ with a cyanide consumption of $2,84 \mathrm{~kg} \cdot \mathrm{t}^{-1}$, while the best gold extraction between biooxidated samples was from bioreactor R2 with $87 \%(30 \mathrm{mg} / \mathrm{L})$, and the cyanide consumption of 2,64 kg.t-1. Experimental results have shown the technical feasibility of the biooxidative prior to convencional leaching for reducing the consumption of reagent cyanide.

Keywords: Gold ore; Acidithiobacillus; Biooxidation; Cyanidation.

\footnotetext{
'Programa de Pós-graduação em Engenharia Química, Laboratório de Bioprocessos, Universidade Federal do Pará - UFPA, Belém, PA, Brasil. E-mail: luanacardosograngeiro@gmail.com

${ }^{2}$ Programa de Pós-graduação em Biotecnologia, Laboratório de Biohidrometalurgia, Universidade Estadual Paulista - UNESP, Araraquara, SP, Brasil. ${ }^{3}$ Laboratório de Bioprocessos, Faculdade de Engenharia Química, Universidade Federal do Pará - UFPA, Belém, PA, Brasil.

${ }^{4}$ Empresa Itatijuca Biotech, São Paulo, SP, Brasil.

${ }^{5}$ Programa de Pós-graduação em Engenharia Química, Universidade Federal do Pará - UFPA, Belém, PA, Brasil.
} 


\section{INTRODUÇÃO}

O ouro é um metal importante para a ciência e para a economia e o desenvolvimento de novas tecnologias para a melhoria da qualidade de vida do homem. A mineração deste metal pode ser realizada de duas formas: garimpagem $e$ mineração industrial. A garimpagem é considerada a primeira técnica de extração de ouro utilizada, principalmente no século XVI. É uma atividade manual rústica a qual envolve seis a oitos homens chamados de garimpeiros os quais utilizam instrumentos como bateia para extrair ouro através de processos de separação gravítica e amalgamação com mercúrio [I]. A cianetação é a principal tecnologia de processamento de minérios auríferos quando se refere a mineração industrial, representando mais de $85 \%$ do ouro extraído no mundo. É uma tecnologia simples para tratar uma enorme variedade de minérios auríferos sejam eles sulfetados ou oxidados. Envolve cianeto disponibilizado em forma de sais como cianeto de sódio $(\mathrm{NaCN})$ o qual é capaz de formar um complexo solúvel estável com ouro chamado ciano-complexo [2]. Porém, quando se trata de minérios sulfetados, o cianeto pode formar complexos com ferro $\left(\mathrm{Fe}(\mathrm{CN})_{6}^{4-}\right)$, com o níquel $\left(\mathrm{Ni}(\mathrm{CN})_{4}^{2-}\right)$, e a prata $\left(\mathrm{Fe}(\mathrm{CN})_{6}^{4-}\right)$, e também outros complexos como íons sulfetos, tiossulfatos e arsenatos devido ao consumo de oxigênio durante a dissolução de ouro na presença do cianeto resultando no consumo de cianeto livre durante este processo. Ainda, estas espécies citadas tendem a precipitar o ouro já oxidado, e o consumo de cianeto pode ser alto devido as reações do cianeto com o cobre e outros minerais de cobre [3-5]. Logo, são necessários pré-tratamentos para superar as dificuldades técnicas como $\circ$ alto consumo de cianeto e incapacidade de libertar o ouro por cianetação [6].

Exemplos de métodos tradicionais de pré-tratamento utilizados são ustulação, lixiviação sob pressão, lixiviação com ácido nítrico entre outros. Estas técnicas apresentam algumas desvantagens econômicas e ambientais, como exemplo, a ustulação apresenta um alto consumo de energia e libera gases poluentes contendo arsênio e enxofre na atmosfera, a lixiviação sob pressão e a lixiviação com ácido nítrico requerem altas temperaturas, altas pressões e materiais resistentes à corrosão gerando, assim, altos custos para - processo. Desta forma, um pré-tratamento alternativo interessante para minérios auríferos pode ser a oxidação biológica ou biolixiviação, alternativa que não gera gases e onde o consumo energético é consideravelmente menor $[3,4,6]$.

A biolixiviação tem sido aplicada para a recuperação de cobre, uranio, zinco, entre outros metais, e também como um pré-tratamento no processo de cianetação. Quando este processo é aplicado a minérios auríferos é também chamada de bioxidação [7]. É baseada na capacidade de um grupo especial de bactérias acidófilas e quimiolitotróficas de utilizar minérios como fonte de energia para 0 seu crescimento e metabolismo e o resultado da atividade destes micro-organismos é a solubilização de metais e a produção de ácido. As bactérias do gênero Acidithiobacillus, Leptospirillum, Sulfolobus e Sulfobacillus são as mais utilizadas neste processo e são capazes de suportar condições extremas de $\mathrm{pH}$, aaltas concentrações de metais e de temperatura. Nos minerais que contem ouro, elas catalisam a oxidação das matrizes sulfetadas tornando o ouro acessível para o processo de dissolução durante a cianetação [8].

O interesse de utilizar técnicas biológicas na extração de ouro tem aumentado devido às vantagens significativas destas em relação às técnicas tradicionais, como a redução das emissões de gases para a atmosfera, a simplicidade de operação, o consumo de energia e reagentes, processo realizado a temperaturas altas acima de $45^{\circ} \mathrm{C}$ e ambiente $\left(27-30^{\circ} \mathrm{C}\right)$, baixo custo e, principalmente, aplicabilidade em minérios refratários ou em recursos minerais que não poderiam ser tratados por meio de técnicas de extração convencionais por apresentar baixa recuperação do metal de interesse $[4,9]$.

Os processos de recuperação de ouro podem apresentar problemáticas devido ao tamanho das partículas, ao baixo conteúdo e a forma de ocorrência ou a natureza do ouro no minério. Além disso, quando se trata da aplicação de bioxidação como pré-tratamento, alguns fatores podem ser limitantes do processo, como $\circ \mathrm{pH}$, quantidade de elementos sulfetados no minério contendo ouro, os tipos de bactérias mais adequadas para o tratamento, entre outros parâmetros que requer atenção e maior estudo antes de serem escolhidos e aplicados. Por isso, o conhecimento das características mineralógicas do minério, a dimensão e liberação da partícula, teor do minério, solubilidade em cianeto, são algumas das características de fundamental importância para o desenvolvimento da melhor rota de extração e concentração do ouro [10]. Dentro deste contexto, o principal objetivo deste trabalho é investigar diferentes rotas biotecnológicas como tratamentos de um minério de ouro proveniente do Estado do Amapá, utilizando a combinação de um processo biohidrometalúrgico (bioxidação) com o processo hidrometalúrgico tradicional (cianetação) para avaliar o consumo de cianeto durante o processo de cianetação.

\section{METODOLOGIA}

\section{I Linhagem Bacteriana e Amostra Mineral}

A linhagem das bactérias At. ferrooxidans - LR e At. thiooxidans $\mathrm{FGOI}$ foram utilizadas para a realização dos ensaios de bioxidação em biorreator e fazem parte do banco de linhagens do laboratório de Biohidrometalurgia - UNESP/Araraquara-São Paulo [1 I, 12]. A amostra mineral coletada para este trabalho (Figura I) foi proveniente da mina Divisão situada no Estado do Amapá, a qual após quarteamento em pilha foi processada em moinho de bola (MLW - KMI) e peneirada (II5 mesh) até atingir uma granulometria $100 \%<0,2 \mathrm{~mm}$. A fim de se determinar as fases cristalinas e a quantidade dos principais metais presentes 


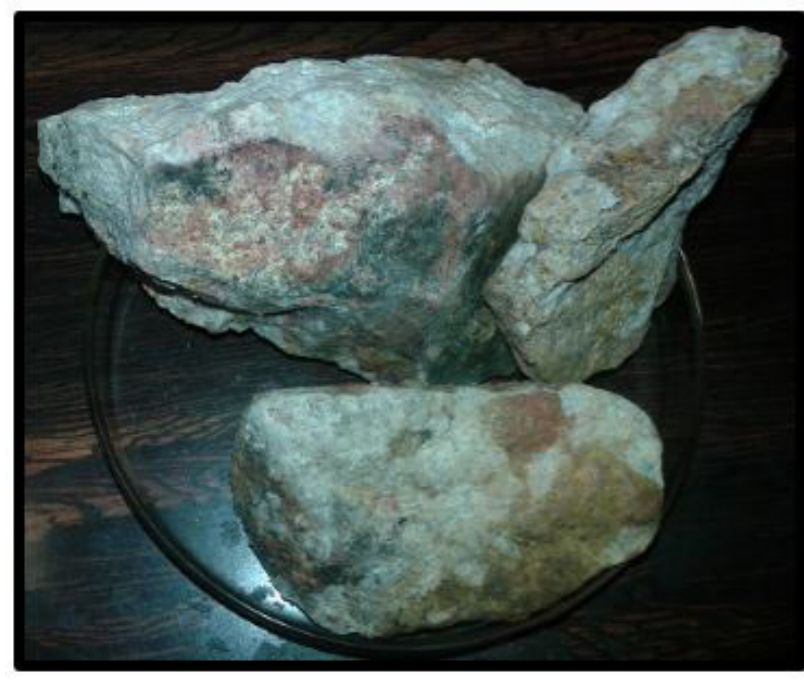

Figura I. Minério aurífero proveniente da mina Divisão.

nas amostras foram realizadas as análises de Difratometria de Raios - X (DRX), Fluorescência de Raios - X (FRX), Espectrometria de Emissão Atômica por Plasma Acoplado Indutivamente (ICP-OES) e para determinar a quantidade de ouro total na amostra foi realizada a análise por Fire Assay pela empresa SGS GEOSOL.

\subsection{Meio de Cultura}

Para a manutenção periódica das linhagens bacterianas foi utilizado o meio de cultura T\&K, desenvolvido por Tuovinen e Kelly [13] e o meio de cultura 9K desenvolvido por Silverman e Lundgren [14]. O meio T\&K modificado utilizado para manutenção da bactéria At. ferrooxidans é composto por sais minerais (Solução A) e sulfato ferroso como fonte de energia (Solução B) [13]. O pH das soluções $A$ e $B$ foi ajustado a I, 8 com ácido sulfúrico $50 \%$. A solução $A$ foi esterilizada por calor úmido em autoclave a $120^{\circ} \mathrm{C}$ por 20 minutos, e a solução $B$ por filtração em membrana de acetato de celulose $(0,45 \mu \mathrm{m}$ de porosidade - marca Milipore). No momento da utilização, a mistura seguiu uma proporção de quatro partes da solução $A$ e uma parte da solução $B$.

O meio de cultura $9 \mathrm{~K}$ utilizado é semelhante ao meio de cultura T\&K, o diferencial é que no meio $9 \mathrm{~K}$ adiciona-se cloreto de potássio e a fonte de energia é o enxofre elementar [14]. $\mathrm{O} \mathrm{pH}$ da solução foi ajustado a $2,8 \mathrm{com}$ ácido sulfúrico $50 \%$. O enxofre elementar foi esterilizado por calor úmido em autoclave a $110^{\circ} \mathrm{C}$ por I hora e logo após adicionado à solução.

\subsection{Ensaio de bioxidação do minério de ouro}

Antes de realizar a cianetação para o estudo da recuperação do ouro contido no minério, a amostra foi submetida a três diferentes pré-tratamentos, sendo dois deles biológicos (Figura 2), Os testes de bioxidação foram realizados em biorreatores com capacidade de $5,5 \mathrm{~L}$ durante

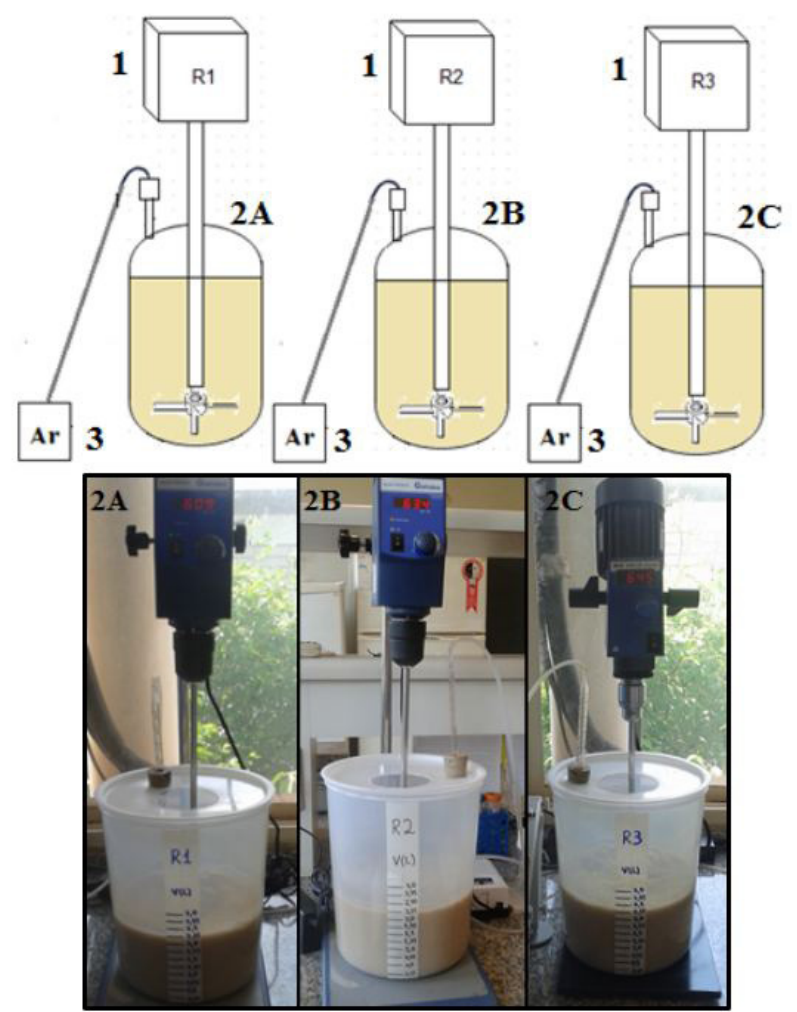

Figura 2. Representação do sistema experimental do processo de bioxidação em biorreator. I) Agitador mecânico de hélice dupla; 2A) Biorreator controle (sem adição de bactéria) (RI); 2B) Biorreator de condição oxidante (R2); 2C) Biorreator de condição ácida (R3); 3) Sistema de aeração ar oxigênio.

20 dias, sob agitação constante e aeração, à temperatura ambiente $\left(25-27^{\circ} \mathrm{C}\right)$. O experimento foi realizado em 3 biorreatores (RI, R2 e R3). O volume final de cada biorreator foi de 2,I L. As condições experimentais estudadas estão descritas a seguir:

- Condição controle (sem adição de bactéria) (RI): Solução A do meio T\&K e $10 \%(\mathrm{~m} / \mathrm{v})$ de minério.

- Condição oxidante (R2): Solução A do meio T\&K inoculado com $10 \%(\mathrm{v} / \mathrm{v})$ de uma cultura fresca de $A t$. ferrooxidans - LR, $10 \%(\mathrm{~m} / \mathrm{v})$ de minério e $100 \mathrm{mmol}$ da fonte energética suplementar (sulfato ferroso).

- Condição ácida (R3): Meio 9K inoculado com 10\% $(\mathrm{v} / \mathrm{v})$ de uma cultura fresca de At. thiooxidans - FGOI, e $10 \%(\mathrm{~m} / \mathrm{v})$ de minério, e $0,5 \%(\mathrm{~m} / \mathrm{v})$ da fonte energética suplementar (enxofre elementar).

Durante o ensaio de bioxidação, o pH foi monitorado nos 7 primeiros dias até que o mesmo se estabilizasse, sendo que quando necessário o $\mathrm{pH}$ foi ajustado com $\mathrm{H}_{2} \mathrm{SO}_{4}$ concentrado para valores próximos de $\mathrm{I}, 8$. Os ensaios foram acompanhados por amostragens periódicas de $10 \mathrm{~mL}$ da suspensão homogênea dos biorreatores. A separação das fases sólida e líquida foi realizada por centrifugação a $4000 \mathrm{rpm}$, a $22^{\circ} \mathrm{C}$ por 5 minutos (Centrífuga Eppendorf $5702 \mathrm{R}$ ). Foram 
realizadas periodicamente medidas de $\mathrm{pH}$, potencial de óxido-redução (Eh) e cobre total. Em cada amostragem, uma alíquota de $5 \mathrm{~mL}$ de amostra foi armazenada em ácido nítrico $2 \%$ (I:I) para determinação de cobre total e ferro total por espectrometria de absorção atômica (Agilent Technologies 200-Series AA). Após a bioxidação de 20 dias, os produtos sólidos totalizaram a massa de aproximadamente $200 \mathrm{~g}$. Esses produtos bioxidados foram filtrados (Figura 3), lavados com água ácida e água deionizada 6 vezes o volume do biorreator, e secos em estufa a $30^{\circ} \mathrm{C}$ overnight antes de serem utilizados no processo de cianetação.

Para melhor entendimento do trabalho desenvolvido, um fluxograma do processo combinado de bioxidação e cianetação pode ser visto na Figura 4. Este circuito apresenta a etapa geral de caracterização do minério a partir do processo de moagem, peneiramento e quarteamento em

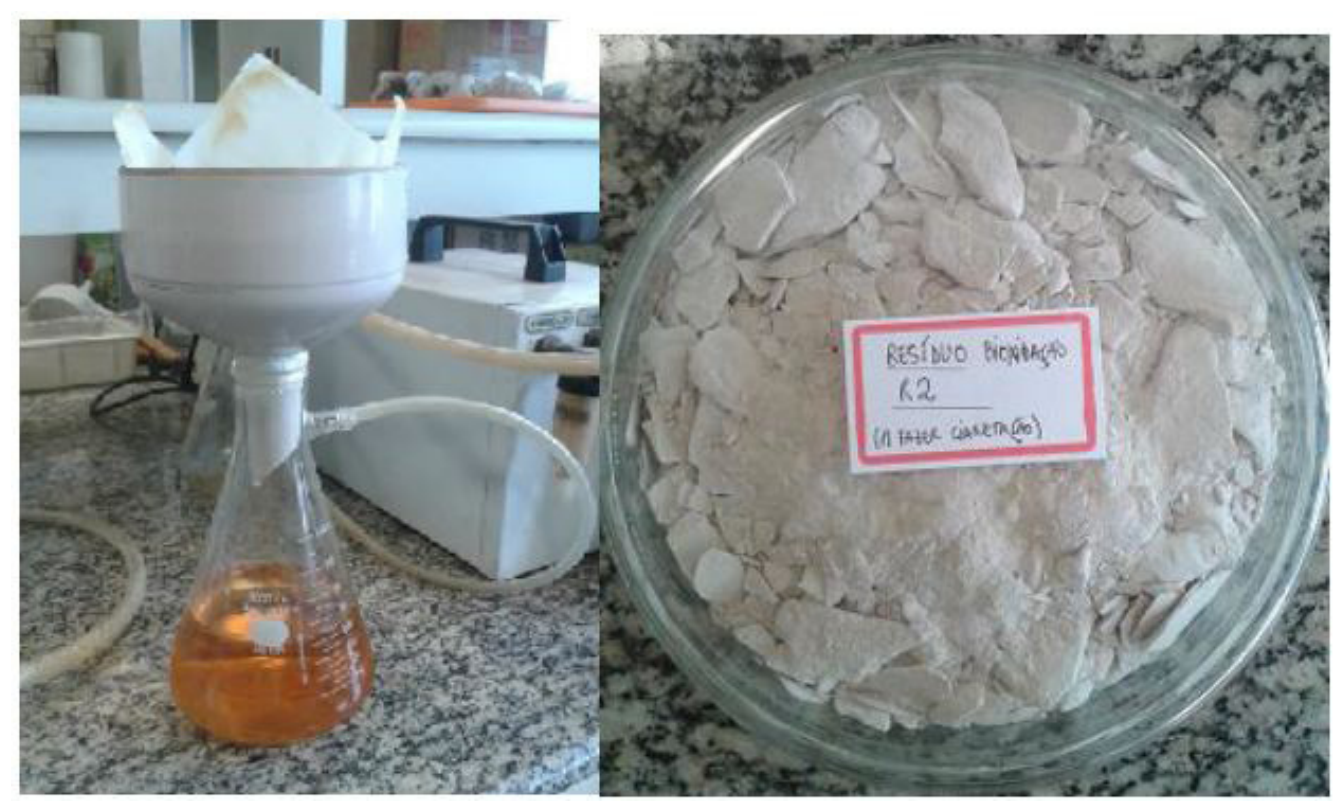

Figura 3. Representação da filtração e do produto bioxidado após secagem em estufa.

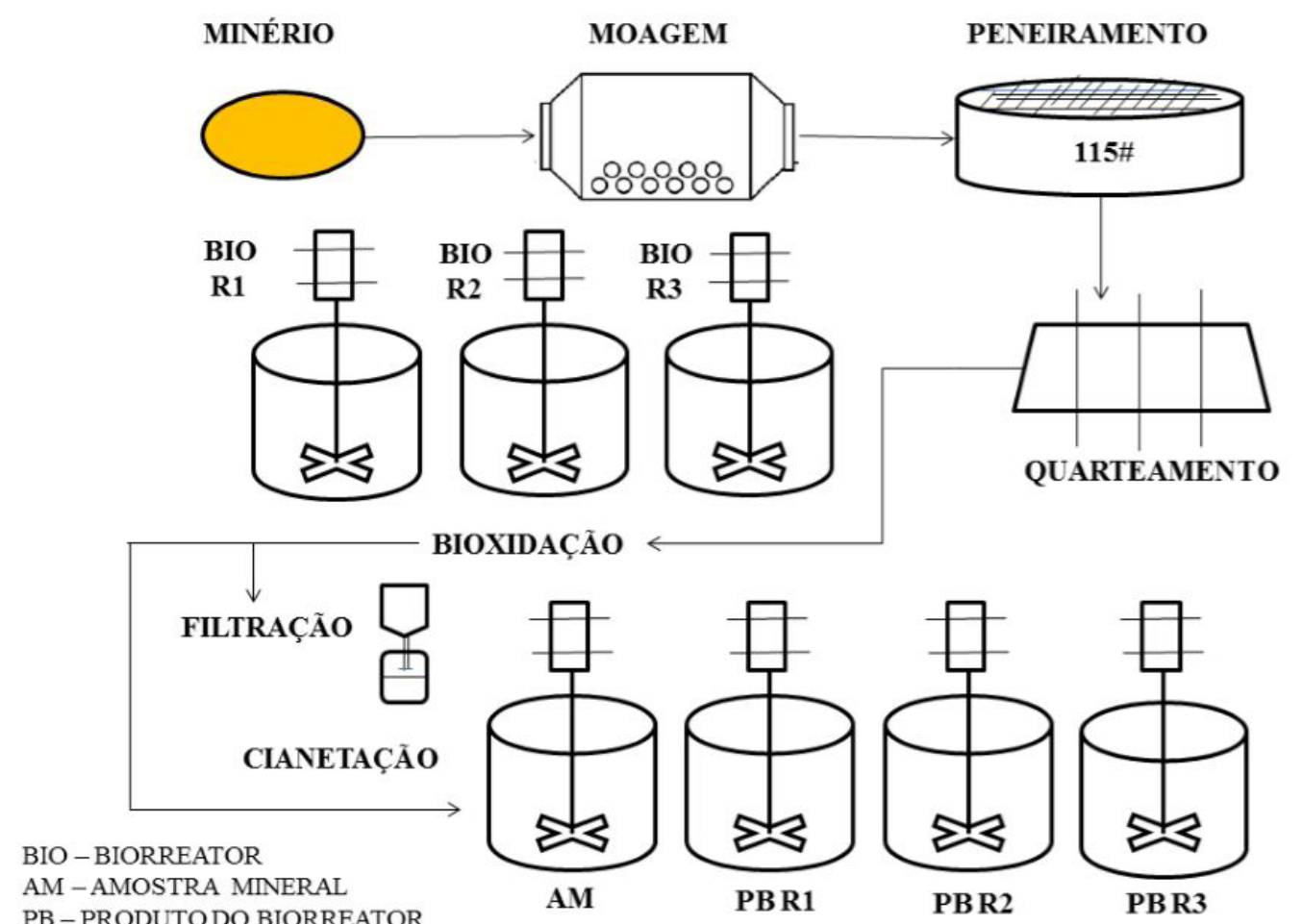

Figura 4. Esquema do fluxograma do processo combinado de bioxidação e cianetação para extração de ouro um minério do Estado do Amapá. 
forma de pilha piramidal longitudinal seguida da fase de pré-tratamento de bioxidação em biorreator pela ação das bactérias do gênero Acidithiobacillus. Após o tratamento biológico, o produto de cada biorreator foi separado e lavado por meio da operação unitária filtração e por fim, realizou-se a etapa de cianetação para recuperação de ouro da amostra sem tratamento e com os produtos bioxidados.

\subsection{Processo de Cianetação}

O ensaio de cianetação foi realizado dentro de uma capela de exaustão (Figura 5). Em um reator foi adicionado à amostra mineral e água destilada de forma que a densidade de polpa para todos os ensaios foi de $16 \%$. Posteriormente, - $\mathrm{pH}$ foi corrigido com $\mathrm{NaOH}$ até estabilização entre 10,5- I I,5. Foi adicionado ao reator uma massa de cianeto de sódio adequada para manter a concentração de cianeto em $2 \mathrm{~g} \mathrm{~L}^{-1}$. Durante as $24 \mathrm{~h}$ de cianetação foram realizadas coletas periódicas de alíquotas de $30 \mathrm{~mL}$ de amostra em diferentes intervalos de tempo(h):, após I hora da adição de cianeto, 3, 6 I 2 e 24. Cada alíquota de $30 \mathrm{~mL}$ retirada foi filtrada, sendo que $5 \mathrm{~mL}$ do líquido foi utilizado para determinar o consumo de cianeto (titulação) e $10 \mathrm{~mL}$ foram utilizados para determinar a concentração de ouro extraído (absorção atômica). Finalizado o processo, deixou-se a polpa decantar no reator, lavou-se o resíduo com água morna (seis vezes o volume do reator) e o mesmo foi colocado para secar em estufa a $70-80^{\circ} \mathrm{C}$. Ao final do ensaio, os resíduos foram filtrados e fez-se o tratamento de degradação do resíduo líquido em bombonas com adição de hipoclorito de sódio o que permite uma eliminação rápida dos cianetos, independente da sua concentração, sem ajustes de pH e com o mais baixo custo de tratamento entre as diferentes técnicas de oxidação. $O$ resíduo sólido foi queimado em latas apropriadas [15].
Para determinação do consumo de cianeto no processo de cianetação foi utilizado o método titulométrico fundamentado na formação de um complexo iônico de prata-cianeto. Este método baseia-se na formação de um complexo iônico de prata de acordo com a Equação I abaixo:

$$
2 \mathrm{CN}^{-}+\mathrm{Ag}^{+} \rightarrow \mathrm{AgCN}_{2}^{-}
$$

Quando todo o cianeto iônico (CN-) estiver complexado com a prata, o excesso de prata é então detectado pelo indicador rodanina. Para a realização da titulação foi utilizado um volume de amostra de $10 \mathrm{~mL}$, em seguida, completou-se o volume a $50 \mathrm{~mL}$ com água deionizada e então adicionou-se $0,5 \mathrm{~mL}$ de rodanina ( $\mathrm{p}$-Dimetilaminobenzilidina) para ser titulado com nitrato de prata $0,0 \mathrm{I} \mathrm{N}$, até a primeira viragem de cor, de amarelo canário para salmão [16].

\subsection{Metodologia Analítica}

\subsection{Medidas de $\mathrm{pH}$ e potencial de óxido-redução} (Eh)

$\mathrm{O} \mathrm{pH}$ e o potencial redox das amostras coletadas foram medidos no sobrenadante utilizando-se pHmetro Corning 430 e um Micronal B374 equipado com um eletrodo de $\mathrm{Ag}|\mathrm{AgCl}| \mathrm{KCl}($ sat), respectivamente.

\subsubsection{Determinação de cobre total}

A concentração de cobre total solúvel após bioxidação nas amostras foi determinada por Espectroscopia de Absorção Atômica (Agilent Technologies série 240 FS AA). O comprimento de onda utilizado para as determinações de cobre foi $324,8 \mathrm{~nm}$, com valor para a fenda espectral de $0,5 \mathrm{~nm}$. A lâmpada utilizada foi a lâmpada de catodo oco
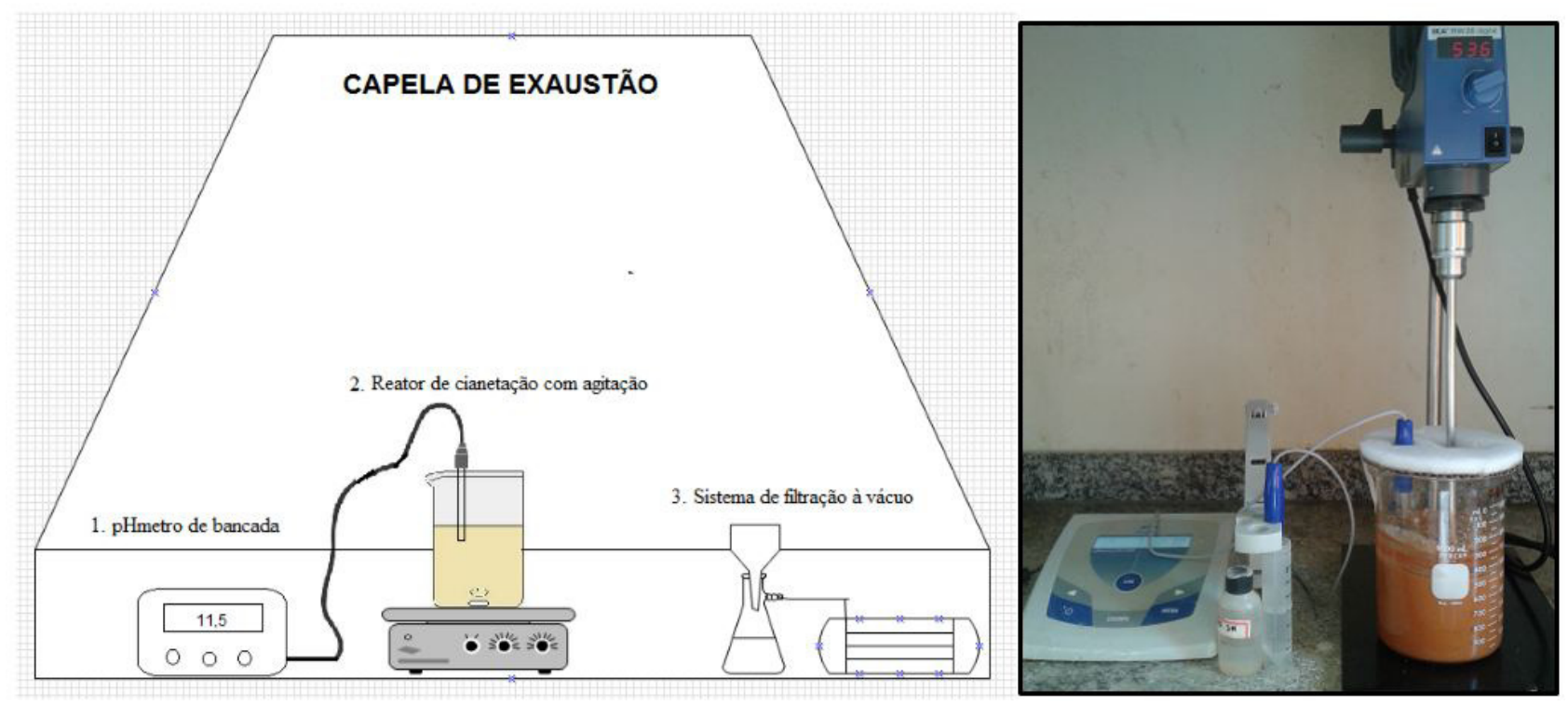

Figura 5. llustração e imagem do sistema experimental utilizado no processo de cianetação. 
multi-elemento $\mathrm{Co} / \mathrm{Cr} / \mathrm{Fe} / \mathrm{Mn} / \mathrm{Ni}$ Varian (Made in Austrália) com uma corrente de $10 \mathrm{~mA}$, e os gases ar e acetileno com vazões de I3,5 $\mathrm{L} \mathrm{min}^{-1}$ e 2,0 $\mathrm{L} \mathrm{min}^{-1}$, respectivamente. É válido destacar que as amostras foram estocadas em torno de $5{ }^{\circ} \mathrm{C}$ em ácido nítrico $2 \%$ numa proporção de $\mathrm{I}: \mathrm{I}$ e, anteriormente às análises, as amostras foram diluídas adequadamente em ácido nítrico $2 \%$.

\subsubsection{Determinação de ouro total}

A concentração de ouro total na amostra original foi realizada pelo método Fire Assay e a determinação de ouro solúvel após a cianetação foi realizado por Espectroscopia de Absorção Atômica (Agilent Technologies série 240 FS AA). O comprimento de onda utilizado para as determinações de ouro foi $242,8 \mathrm{~nm}$, com valor para a fenda espectral de $I, 0 \mathrm{~nm}$. A lâmpada utilizada foi a lâmpada de catodo oco Agilent Au (Made in Austrália) com uma corrente de $10 \mathrm{~mA}$, e os gases ar e acetileno com vazões de $13,5 \mathrm{~L} \mathrm{~min}^{-1}$ e 2,0 L min-1, respectivamente.

\subsection{Caracterização da Fase Sólida}

\subsection{Quarteamento em pilha}

Antes de iniciar o processo de caracterização das amostras minerais foi realizado o quarteamento em forma de pilha longitudinal piramidal do minério para separa-lo em partes de amostras representativas e consequentemente obter dados também representativos e confiáveis durante o experimento. A aplicação da técnica de quarteamento em forma de pilha garante a total homogeneização da amostra [I7].

\subsubsection{Difração de raios X (DRX)}

Neste trabalho foram realizadas análises de DRX (D5000 - Siemens) na amostra original de minério. Antes de ser submetido à análise, o minério foi cominuido em moinho de bolas, pulverizado em almofariz e peneirado até atingir a granulometria desejada.

\section{RESULTADOS E DISCUSSÕES}

\section{I Caracterizações da Amostra}

Após o quarteamento, a amostra foi submetida à análise de difratometria de raios $X$, onde foi possível observar que a sua composição predominante é a sílica (Figura 6). Não foi possível detectar ouro, cobre e ferro através de DRX, pois estes elementos encontram-se em quantidades menores que o limite de detecção da análise. Por isso, foram realizadas análises de Fire Assay para determinar a quantidade de ouro total na amostra (Tabela I), FRX (Tabela 2) e ICP - OES do minério (Tabela 3 ) no intuito de quebrar a matriz

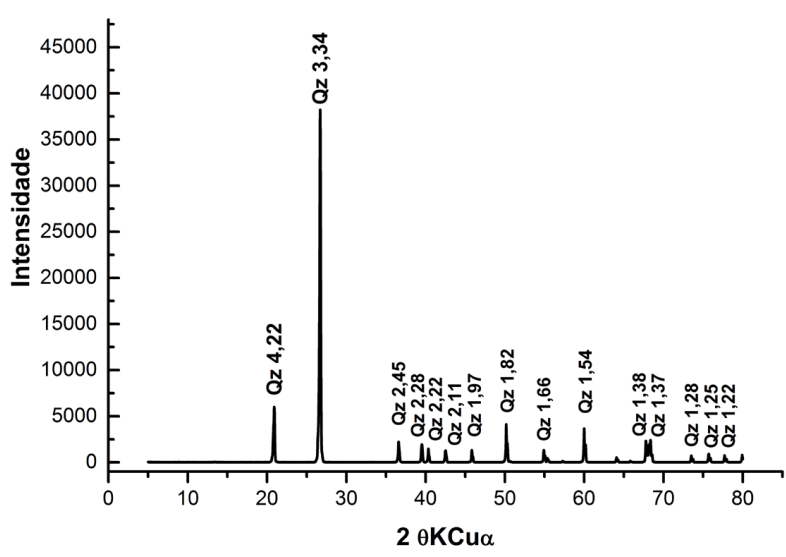

Figura 6. Difratograma de raios $X$ da amostra de minério de ouro utilizada nos experimentos de bioxidação. Símbolos: $\mathrm{Qz}$, quartzo. A barra lateral indica a intensidade dos picos e o número acima da identificação do pico indica a distância "d" (em Ăngstrons) característica da fase cristalina.

Tabela I. Resultados obtidos pelo Fire Assay

\begin{tabular}{cc}
\hline \multicolumn{2}{c}{ Fire Assay } \\
\hline Metal & Concentração (ppb) \\
\hline Ouro $(\mathrm{Au})$ & 90187 \\
Paládio $(\mathrm{Pd})$ & $<$ L.D. 5 \\
Platina $(\mathrm{Pt})$ & $<$ L.D. 5 \\
\hline
\end{tabular}

Tabela 2. Fluorescência de Raios $X$ da amostra mineral

\begin{tabular}{cc}
\hline \multicolumn{2}{c}{ Fluorescência de Raios $\mathbf{X}$} \\
\hline Parâmetro & Concentração (\%) \\
\hline Sílica $\left(\mathrm{SiO}_{2}\right)$ & 97,7 \\
Ferro $\left(\mathrm{Fe}_{2} \mathrm{O}_{3}\right)$ & 0,76 \\
Alumínio $\left(\mathrm{Al}_{2} \mathrm{O}_{3}\right)$ & 0,31 \\
Cálcio $(\mathrm{CaO})$ & 0,02 \\
Titânio $\left(\mathrm{TiO}_{2}\right)$ & 0,02 \\
Potássio $\left(\mathrm{K}_{2} \mathrm{O}\right)$ & 0,02 \\
Manganês $(\mathrm{MnO})$ & 0,05 \\
Magnésio $(\mathrm{MgO})$ & $<$ L.D. 0,01 \\
Fósforo $\left(\mathrm{P}_{2} \mathrm{O}_{5}\right)$ & $<$ L.D. 0,01 \\
Sódio $\left(\mathrm{Na}_{2} \mathrm{O}\right)$ & $<$ L.D. 0,01 \\
\hline
\end{tabular}

Tabela 3. Análise ICP - OES da amostra mineral

\begin{tabular}{ccc}
\hline & ICP OES & \\
\hline Elemento & Concentração & Unidade \\
\hline Ferro & 0,54 & $\%$ \\
Potássio & 0,02 & $\%$ \\
Cobre & 119 & $\mathrm{Ppm}$ \\
Alumínio & 0,14 & $\%$ \\
Manganês & 0,04 & $\%$ \\
Níquel & 109 & $\mathrm{Ppm}$ \\
Cálcio & 0,02 & $\%$ \\
Bário & 92 & $\mathrm{ppm}$ \\
Cromo & 58 & $\mathrm{ppm}$ \\
Chumbo & 34 & $\mathrm{ppm}$ \\
Zinco & 18 & $\mathrm{ppm}$ \\
Zircônio & 6 & $\mathrm{ppm}$ \\
\hline
\end{tabular}


cristalina da amostra e liberar os metais para determinação, principalmente, do teor cobre, ferro e quartzo. Face ao exposto, foram obtidos $90187 \mathrm{ppb}$ de ouro (2-3\% teor de $\mathrm{Au}), 0,54 \%(\mathrm{~m} / \mathrm{m})$ de ferro, $119 \mathrm{ppm}$ de cobre e $97,7 \%$ $(\mathrm{m} / \mathrm{m})$ de sílica confirmando o resultado do difratograma. É de extrema importância ressaltar que nenhuma das análises realizadas apontou para a presença de sulfetos na amostra estudada, uma vez que esta apresenta ouro associado a quartzo e outros silicatos, e não a sulfetos.

\subsection{Ensaio de Bioxidação do Minério de Ouro}

Considerando as condições propostas na metodologia, a aquisição dos resultados experimentais foi obtida utilizando cepas das bactérias At. ferrooxidans e At. thiooxidans isoladas e aplicadas em minério aurífero não estéril.

$\mathrm{Na}$ Figura 7 estão apresentados os valores de $\mathrm{pH}$, potencial de óxido-redução e a porcentagem de cobre extraído em função do tempo de ensaio, para a condição controle.

O ensaio sem a bactéria com o minério não estéril apresentou um comportamento parecido com os meios inoculados. Isto pode ser explicado pelo crescimento microbiano dos microrganismos nativos do minério que podem estar aderidos na superfície desse material uma vez que foram fornecidas as condições ótimas para seu crescimento. Assim, os valores aumentaram na primeira

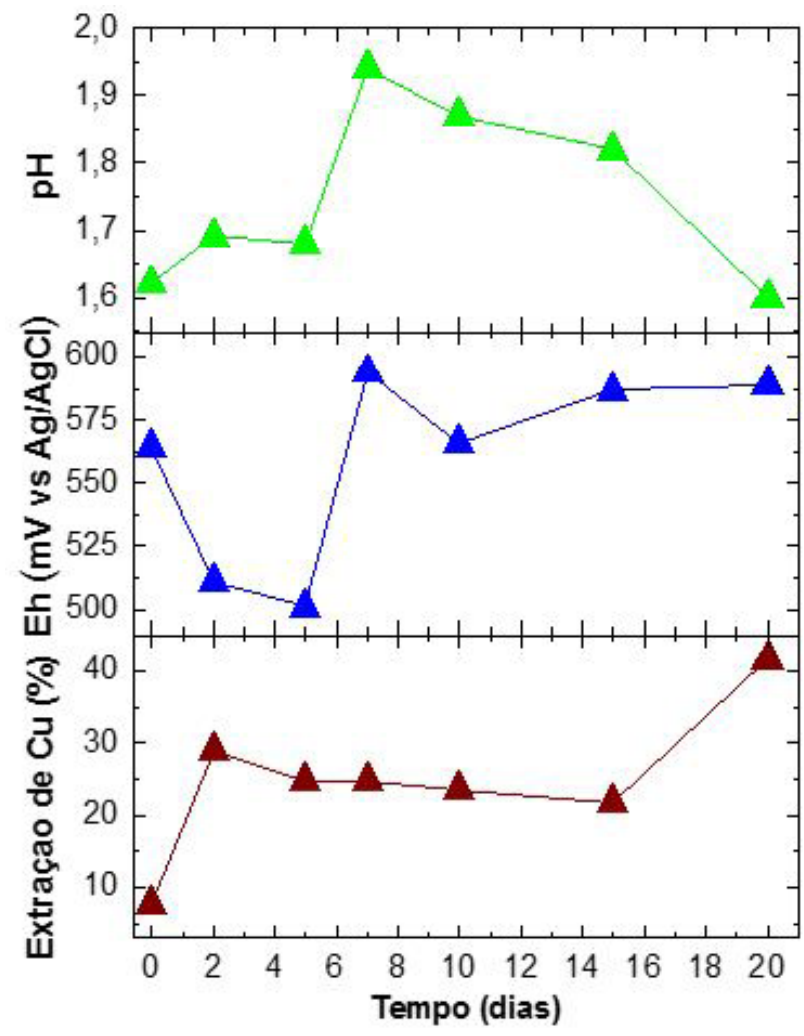

Figura 7. Variação do pH, Eh e porcentagem de extração de cobre no experimento de bioxidação no biorreator controle (RI) em função ao tempo. semana de ensaio (7 dias) e diminuíram após esse período até alcançar o valor de I,6. É importante saber que a dissolução do mineral pode ser tanto produtora como formadora de ácido [18], logo o aumento do $\mathrm{pH}$ na primeira semana pode indicar o consumo ácido pela própria amostra, e a diminuição do $\mathrm{pH}$ após esse período provavelmente está associado a geração ácida através das reações bacterianas por parte de bactérias nativas da própria amostra mineral uma vez que não foi adicionada bactéria nesta condição. Para confirmar o desenvolvimento de bactérias da própria amostra foi necessário realizar o estudo da viabilidade celular do sistema

Em relação as medidas de potencial de óxido-redução, pode-se observar que nos 5 primeiros dias ocorreu uma queda no potencial da amostra, isto pode estar relacionado com a pequena atividade iônica dos íons ferrosos presentes no sistema e ainda a baixa relação $\mathrm{Fe}^{+3} / \mathrm{Fe}^{+2}$, pois sabe-se o potencial redox independe da concentração de íons ferrosos presentes em solução, porém é considerado função da atividade iônica destes íons e da relação do par $\mathrm{Fe}^{+3} / \mathrm{Fe}^{+2}$. Após o quinto dia de ensaio, o potencial de óxido-redução (Eh) aumentou consideravelmente e atingiu valores próximos de $600 \mathrm{mV}$. É importante destacar que na presença da bactéria, o Eh é denominado em função do par $\mathrm{Fe}^{+3} / \mathrm{Fe}^{+2}$, e com a ocorrência da ação oxidante da bactéria na amostra mineral, este potencial tende a aumentar até atingir um valor próximo de $600 \mathrm{mV}$, o que evidencia a oxidação de em indicando atividade bacteriana [19]. Portanto, é possível concluir que no biorreator $\mathrm{RI}$ as bactérias nativas da amostra mineral se desenvolveram, oxidando íons ferrosos e elevando o potencial.

Finalmente, nesta condição (RI), a extração de cobre atingiu $20 \%$ até o segundo dia de ensaio, o que sugere a presença de cobre na forma de óxidos uma vez que a amostra estudada não apresentou sulfetos. A partir deste dia, a extração do metal foi constante até atingir uma extração de cobre máxima de $4 I, 74 \%$. Diversos estudos mostram que, em altos valores de potencial (acima de $560 \mathrm{mV}$ ), a solubilização de cobre é estritamente limitada [20]. Os dados obtidos no ensaio confirmam estas afirmações.

Para a condição inoculada com At. ferrooxidans em meio de cultivo T\&K com adição de fonte energética suplementar, os ensaios foram realizados como pré-tratamento do minério a fim de minimizar a concentração de cobre, e reduzir o consumo de cianeto no processo de cianetação. De modo geral, a bactéria At. ferrooxidans apresenta a capacidade de oxidar íons ferrosos de maneira bem rápida e eficiente. $\mathrm{Na}$ Figura 8 estão apresentados os valores de $\mathrm{pH}$, potencial de óxido-redução e a porcentagem de cobre extraído em função do tempo de ensaio. Logo, o íon ferroso é adicionado apenas como iniciador do processo metabólico da espécie para gerar o ambiente oxidante capaz de solubilizar os óxidos de cobre presentes na amostra mineral.

Os valores de $\mathrm{pH}$ apresentaram pequenas variações com o tempo e atingiram valores superiores a 2,0, o que exigiu a correção ácida para valores abaixo de 2,0 com ácido sulfúrico concentrado. Os ajustes dos valores de $\mathrm{pH}$ (indicado 
pelas setas pretas) são necessários porque valores de $\mathrm{pH}$ na faixa de 2 a 3 favorecem reações de precipitação de ferro na forma de jarosita $\left[\mathrm{MFe}_{3}\left(\mathrm{SO}_{4}\right) 2(\mathrm{OH})_{6}\right]$, o que pode interferir na solubilização do metal de interesse e ainda ajudam a manter as condições ótimas para o crescimento e atividade bacteriana [2I]. Após $\circ 5^{\circ}$ dia de ensaio não foram necessárias mais correções ácidas no biorreator. $\mathrm{O}$ aumento inicial do $\mathrm{pH}$ deve-se a dois fatores principais, o primeiro é o consumo ácido pela própria amostra mineral e a produção de ácido, como também foi observado na condição controle. No entanto, neste caso a oxidação do íon ferroso pela At. ferrooxidans a íon férrico também consome ácido como mostra a Equação 2 [4].

$$
4 \mathrm{FeSO}_{4}+\mathrm{O}_{2}+2 \mathrm{H}_{2} \mathrm{SO}_{4} \rightarrow 2 \mathrm{Fe}\left(\mathrm{SO}_{4}\right)_{3}+2 \mathrm{H}_{2} \mathrm{O}
$$

Esta ação bacteriana pode ser confirmada com os valores do $\mathrm{pH}$ pois sabe-se que a espécie At. ferrooxidans normalmente cresce em uma faixa de $\mathrm{pH}$ de I,5-6,0 com $\mathrm{pH}$ ótimo variando de 2,0 a 2,5, mas normalmente não sobrevive abaixo de I,0 e nem acima de 7,0 [22]. Nesta condição, o potencial de óxido-redução aumentou de $389 \mathrm{mV}$ a $600 \mathrm{mV}$ em apenas dois dias de ensaio. Este comportamento evidencia a oxidação bacteriana dos íons ferrosos no sistema de biorreator pela presença da bactéria o que permitiu a alta relação do $\mathrm{par} \mathrm{Fe}^{+3} / \mathrm{Fe}^{+2}$, ou seja, sua capacidade de capturar ou liberar elétrons.

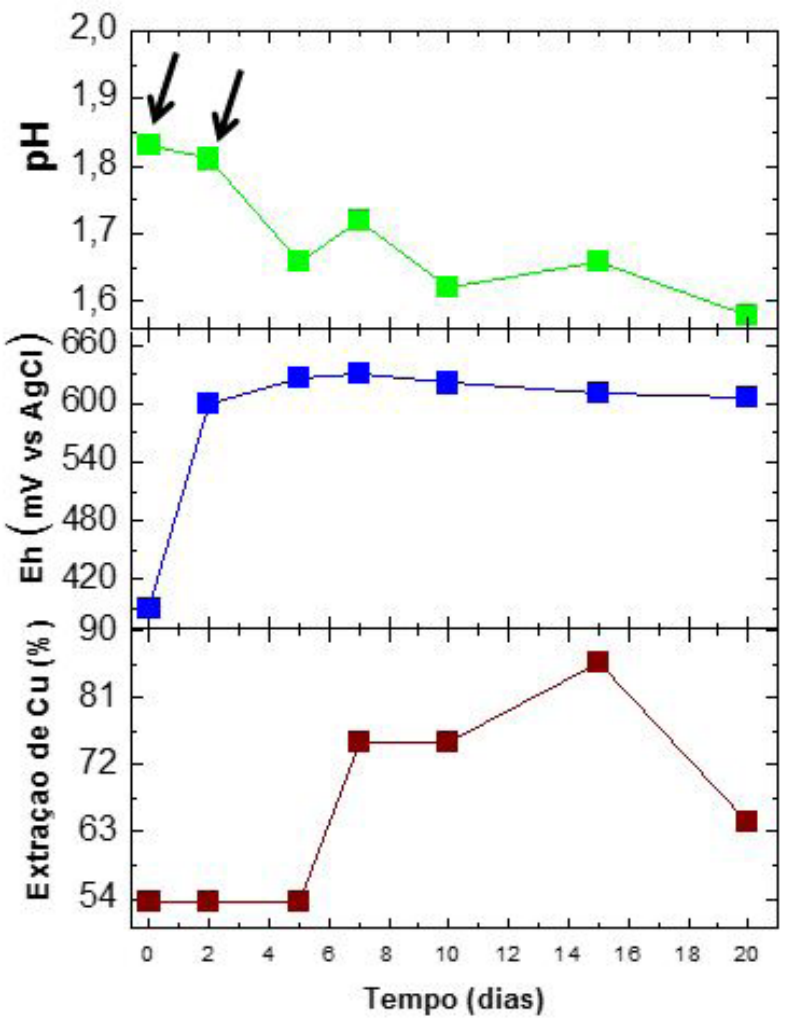

Figura 8. Variação do pH, Eh e porcentagem de extração de cobre no experimento de bioxidação no biorreator de condição oxidante (R2) em função do tempo.
A extração de cobre manteve-se constante em torno de $50 \%$ até $\circ 5^{\circ}$ dia. A partir deste dia, a extração aumentou até atingir a porcentagem máxima de $83 \%$ e posteriormente, no último dia de ensaio, esta extração reduziu para $64,29 \%$. Esta queda na extração de cobre é improvável, pois significaria a redução de cobre na lixívia, uma vez já extraído. Portanto, considerando que o experimento não apresentou repetições associa-se os motivos e razões destes resultados a erros experimentais, ainda não identificados e explicados. Esta condição apresentou a maior extração de cobre quando comparada com as demais estudadas. Isto evidencia que a adição de íons ferrosos ao sistema estudado na presença de At. ferrooxidans favorece a maior solubilização de cobre.

$\mathrm{Na}$ Figura 9 estão apresentados os valores de $\mathrm{pH}$, potencial de óxido-redução e a porcentagem de cobre extraído em função do tempo para a condição ácida. O enxofre elementar é adicionado apenas como iniciador do processo metabólico da espécie para gerar o ambiente ácido capaz de solubilizar os óxidos de cobre presentes na amostra mineral.

Os resultados obtidos do ensaio inoculado com a At. thiooxidans possuem como característica de sua atividade microbiana a produção de ácido e consequentemente a diminuição dos valores de $\mathrm{pH}$. Assim, é possível observar essa diminuição desde o primeiro dia de ensaio. Esta diminuição do $\mathrm{pH}$ está associada à produção de ácido sulfúrico como

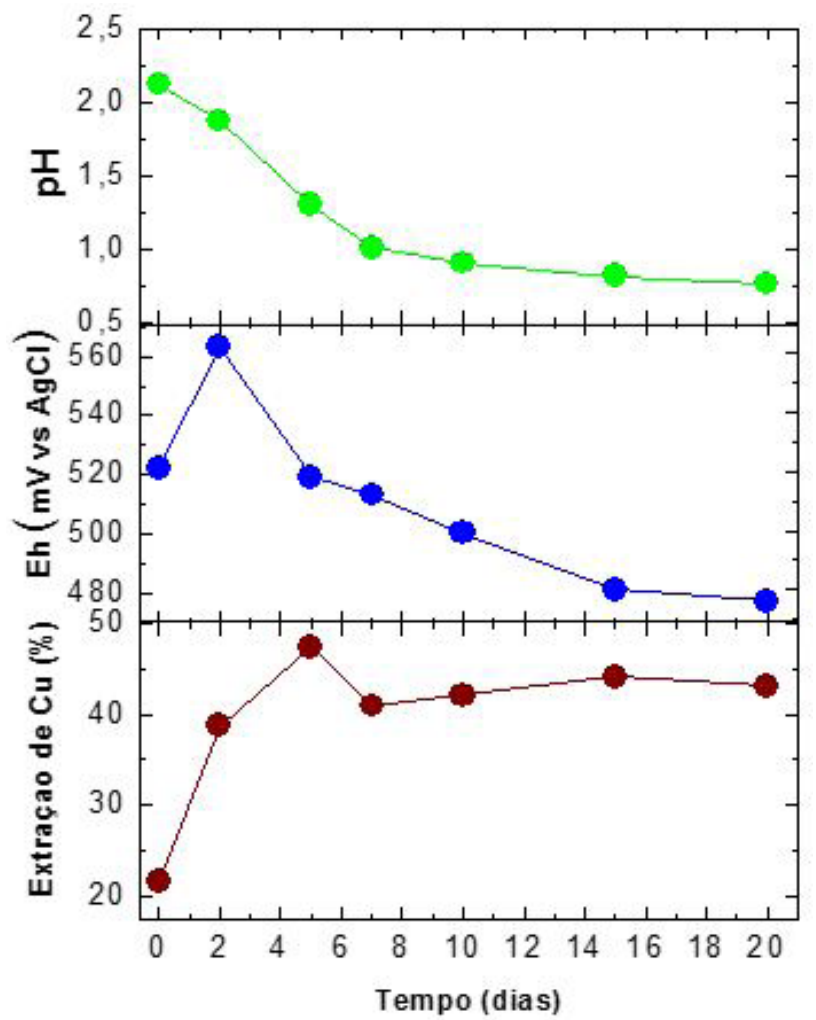

Figura 9. Variação do pH, Eh e porcentagem de extração de cobre no experimento de bioxidação no biorreator de condição ácida (R3) em função do tempo. 
resultado da oxidação de compostos reduzidos de enxofre ação característica da espécie At. thiooxidans [23-25].

Neste ensaio, a variação do Eh foi pequena. Tais valores até $\circ 10^{\circ}$ dia são altos e após este dia eles diminuem e permanecem em torno de $470-480 \mathrm{mV}$. As bactérias At. thiooxidans utilizam apenas compostos reduzidos de enxofre como fonte energética não utilizando portanto o ferro. Desta forma, a mudança no valor do Eh se deve apenas a oxidação química natural da amostra mineral no meio lixiviante que é favorecido no ensaio inoculado devido à produção de ácido sulfúrico pela bactéria. A extração de cobre aumentou até o quinto dia atingindo uma porcentagem de extração máxima em torno de $48 \%$. A partir do sexto dia, ocorreu uma queda na extração do metal para $40 \%$ e esta extração manteve-se em torno de $40 \%$ até o último de ensaio a qual foi de $43,05 \%$. Estes resultados mostram que a adição de enxofre elementar para gerar a condição ácida não foi tão eficiente na solubilização de cobre quando comparada com a condição oxidante, a qual utilizou íons ferrosos como fonte de energia suplementar.

A maioria dos estudos de redução de elementos que consomem cianeto como cobre e ferro são realizados com amostras auríferas sulfetadas. Neste trabalho utilizou-se uma amostra aurífera associada a quartzo e outros silicatos o que impossibilita, em alguns momentos, realizar comparações de resultados das condições estudadas.

A significativa queda observada nos valores do $\mathrm{pH}$ se deve a produção de ácido pela bactéria, isto é, a elevada produção de ácido se refletiu na medida final do $\mathrm{pH}$ de valor 0,77 . A produção de ácido sulfúrico pela bactéria At. thiooxidans funciona como agente corrosivo [26].

Em linhas gerais, os fatores chaves para uma biolixiviação otimizada para as bactérias oxidantes de ferro são baixos valores iniciais de $\mathrm{Fe}^{3+}$, baixo valor de potencial e concentrações suficientes de $\mathrm{Fe}^{2+}$.Para as bactérias oxidantes de enxofre é preciso concentrações suficientes de enxofre elementar ou suas formas reduzidas. Deve-se controlar o pH para mantê-lo na faixa de 2-4 para as bactérias acidófilas. Podem-se utilizar temperaturas ambientes $\left(27-30^{\circ} \mathrm{C}\right)$ ou ainda altas temperaturas acima de $45^{\circ} \mathrm{C}$ caracterizando micro-organismos termófilos moderados e extremos, a escolha e a classificação do micro-organismo dependerão da temperatura de operação do processo [27].

\subsection{Processo de Cianetação}

A Figura 10 apresenta os dados de porcentagem de ouro extraído no processo de cianetação com as quatro diferentes amostras e a quantidade em massa de cianeto consumida durante as 24 horas de ensaio.

É possível observar que a cianetação da amostra mineral (sem qualquer tipo de tratamento) obteve uma recuperação de ouro de $93 \%$, enquanto o resíduo proveniente do biorreator R2 (condição oxidante) apresentou uma recuperação de $87 \%$. Estes resultados são considerados semelhantes uma vez que não ocorreu repetição deste

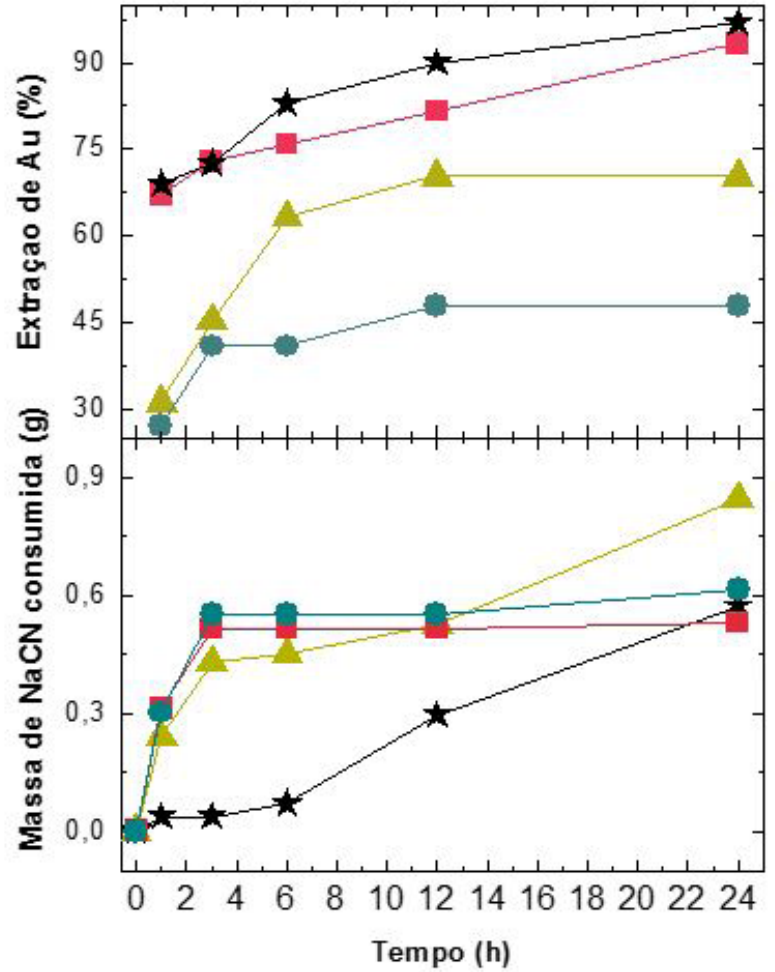

Figura 10. Variação da porcentagem de ouro extraído e variação da massa de $\mathrm{NaCN}$ consumida em função do tempo de cianetação, para as amostras distintas: amostra mineral sem tratamento $(\star)$, resíduo da bioxidação RI ( $\Delta)$, resíduo da bioxidação $R 2$ ( $\square$ ) e resíduo do bioxidação R3 $(\bullet)$.

experimento permitindo valores em duplicata ou triplicata para realização de um estudo estatístico. Logo, a condição oxidante (R2) apresentou resultado positivo de extração de ouro. Os resultados obtidos da cianetação do resíduo proveniente do biorreator RI (condição controle) e da cianetação do resíduo proveniente do biorreator R3 (condição ácida) foram $65 \%$ e $43 \%$ de recuperação de ouro, respectivamente. Esses resultados mostram que as rotas biotecnológicas RI e R3 não melhoraram a porcentagem de extração de ouro, logo não são aplicáveis ao minério em estudo.

Diversos estudos na literatura mostram que a aplicação de pré-tratamento de bioxidação antes do processo de cianetação em amostras auríferas, principalmente sulfetadas, resulta no aumento do rendimento de extração de ouro de $35 \%$ para $95 \%$. A aplicação da bioxidação como pré-tratamento de um minério aurífero arsenopíritico aumentou a extração de $55,3 \%$ (cianetação da amostra mineral) para 92, 3\% (cianetação após a bioxidação) [6]. Ubaldini e colaboradores [3] realizaram estudos da viabilidade da aplicação de oxidação biológica antes do processo de cianetação. O resultado obtido para a extração de ouro do processo de $24 \mathrm{~h}$ de cianetação com a amostra aurífera pirrotita sem tratamento evidenciou uma recuperação deste metal menor que $20 \%$, enquanto a cianetação de 
24h da amostra aurífera realizada após o pré-tratamento de bioxidação apresentou a recuperação de ouro em torno de $91 \%$, o que evidenciou o aumento do rendimento de extração de ouro em torno de $86 \%$ confirmando a eficácia de aplicar o pré-tratamento de bioxidação antes de realizar o processo de cianetação. Curreli e colaboradores [28] investigaram a aplicação de dois pré-tratamentos para um concentrado sulfetado, antes do processo de cianetação: a ustulação e a bioxidação. Os resultados obtidos mostraram a cianetação após o pré-tratamento de ustulação apresentou uma extração de ouro de $85 \%$ enquanto a cianetação após o pré-tratamento de bioxidação apresentou uma extração de ouro de $77 \%$. Eles consideraram que os resultados foram próximos, uma vez que não foram realizadas repetições e confirmaram a eficácia da aplicação destas técnicas como pré-tratamento. Os autores associam o menor valor de extração de ouro do processo biohidrometalúrgico a fatores como a alta porosidade conferida aos grãos minerais pela ustulação o que proporcionou aos grãos de ouro maior acessibilidade as soluções de cianeto. Entretanto, os autores consideraram a técnica de bioxidação a melhor escolha para o pré-tratamento devido as vantagens como simples operação, menor gasto de insumos e, principalmente, a não liberação de poluentes para a atmosfera como acontece no processo de ustulação.

Em relação a massa de cianeto de sódio $(\mathrm{NaCN})$ consumida no processo, é possível observar que a amostra mineral consumiu em torno de $0,5 \mathrm{~g}$ do reagente e o menor consumo ocorreu na rota biotecnológica R2 (condição oxidante). Esse resultado era esperado, uma vez que esta rota apresentou a maior extração do elemento cianicida cobre durante os ensaios de bioxidação. As rotas RI e R3 apresentaram os maiores valores de consumo de massa de cianeto com $0,6 \mathrm{~g}$ e $0,9 \mathrm{~g}$ respectivamente.

Pode ser observado na Tabela 4 que o consumo de cianeto diminuiu de $2,86 \mathrm{~kg} \cdot \mathrm{t}^{-1}$ (amostra mineral) para 2,64 kg. $t^{-1}$ na cianetação no biorreator R2 o que mostrou uma redução do consumo de cianeto. A cianetação no biorreator RI $\left(4,28 \mathrm{~kg} \cdot t^{-1}\right)$ e a cianetação no biorreator R3 $\left(3,18 \mathrm{~kg} \cdot \mathrm{t}^{-1}\right)$ apresentaram os maiores valores de consumo de cianeto e podem ser explicados pela presença de ferro e cobre na amostra, os quais são elementos que competem com ○ ouro, já que o cianeto não é um reagente seletivo e em solução pode-se ligar com cobre, ferro e outros elementos

Tabela 4. Resultados obtidos para o consumo de $\mathrm{NaOH}$ e $\mathrm{NaCN}$ durante o processo de cianetação direta (sem pré-tratamento) e cianetação com os resíduos bioxidados

\begin{tabular}{cccc}
\hline Processo & $\begin{array}{c}\text { Extração } \\
\text { de Au (\%) }\end{array}$ & $\begin{array}{c}\mathbf{N a O H} \\
\left(\mathbf{k g . t ^ { - 1 } )}\right.\end{array}$ & $\begin{array}{c}\mathbf{N a C N} \\
\left(\mathbf{k g} \cdot \mathbf{t}^{-1}\right)\end{array}$ \\
\hline Cianetação direta & $\mathbf{9 3}$ & $\mathbf{0 , 5 0}$ & $\mathbf{2 , 8 6}$ \\
Cianetação após Bioxidação RI & 65 & $0,5 \mathrm{I}$ & 4,28 \\
Cianetação após Bioxidação R2 & $\mathbf{8 7}$ & $\mathbf{5 , 1 5}$ & $\mathbf{2 , 6 4}$ \\
Cianetação após Bioxidação R3 & 43 & 1,24 & 3,18 \\
\hline
\end{tabular}

nas primeiras horas de cianetação [4,5]. Ainda nesta tabela, é possível destacar o alto consumo do reagente hidróxido de sódio $(\mathrm{NaOH})$ no biorreator $\mathrm{R} 2$ o que pode estar relacionado com a necessidade de neutralizar o ácido produzido na polpa bioxidada, pois apenas lavou-se o resíduo com água ácida para retirar os possíveis precipitados de ferro gerados no ensaio de bioxidação. De acordo com Ubaldini [4], em pré-tratamentos de bioxidação utilizando a bactéria do gênero Acidithiobacillus é aconselhável neutralizar as polpas bioxidadas antes de iniciar o processo de cianetação a fim de evitar o alto consumo de $\mathrm{NaOH}$. Neste trabalho não ocorreu a neutralização da polpa bioxidada.

\section{CONCLUSÃO}

Neste estudo foi demonstrado que para a amostra mineral utilizada não seria necessário aplicar as rotas biotecnológicas RI e R3 como pré-tratamentos antes da realização do processo de cianetação. Os ensaios de bioxidação RI sem bactéria e R3 de condição ácida na presença de At. thiooxidans com adição de fonte energética suplementar foram considerados menos eficientes na redução de teor de cobre inicial na amostra mineral com $41 \%$ e $43 \%$, respectivamente. Estes dois pré-tratamentos realizados ao invés de diminuir o consumo de cianeto, de uma forma geral aumentaram, portanto, acarretariam aumento nos custos operacionais do processo.

A porcentagem de extração de ouro nas rotas RI e R3 foram respectivamente $65 \%$ e $41 \%$, menores que a extração de ouro na cianetação com a amostra mineral com $93 \%$. Todavia, a rota biotecnológica R2 condição oxidante na presença de At. ferrooxidans apresentou a maior recuperação de ouro. Neste sistema a adição de íons ferrosos melhorou a taxa de extração de cobre a qual foi a maior com $64 \%$ dos sistemas testados. Isto, consequentemente favoreceu a recuperação de ouro a qual foi bem aproximada (87\%) da amostra mineral, e a redução do consumo de cianeto atingindo um valor menor $\left(2,64 \mathrm{~kg} \mathrm{ton}^{-1}\right)$ comparado ao consumo da amostra mineral $\left(2,86 \mathrm{~kg}^{-1}\right.$ ton $\left.^{-1}\right)$ e as outras condições estudadas. Portanto, este pré-tratamento foi eficaz quando se trata da redução de consumo e economia de cianeto. $E \mathrm{~m}$ relação a extração de ouro sugere-se que mais estudos sejam realizados para confirmar os resultados desta técnica e alcançar rendimentos maiores de extração do metal. Ainda, na rota R2 ocorreu o maior consumo de reagente $\mathrm{NaOH}$ devido à falta de neutralização do resíduo proveniente da bioxidação antes de realizar o processo de cianetação. Nas demais condições estudadas, o consumo de $\mathrm{NaOH}$ foi menor.

Sugere-se que em trabalhos futuros seja realizado um estudo mineralógico mais detalhado da amostra mineral utilizada neste trabalho para observar outros elementos interferentes na cianetação, além do cobre. Isto pode ajudar na determinação da melhor rota biotecnológica a ser 
aplicada como pré-tratamento para alcançar os máximos valores de extração de ouro e de redução no consumo de cianeto. Também é interessante realizar o processo em escala piloto para um estudo completo da avaliação de custo/benefício do processo, pois a avaliação econômica entre custos de reagentes e porcentagens de extração pode tornar o processo viável e mais ambientalmente amigável, mesmo que a extração não seja a máxima.

\section{Agradecimentos}

Os autores agradecem à Universidade Federal do Pará (UFPA), ao Programa de Pós-Graduação em Engenharia Química da UFPA, ao Conselho Nacional de Desenvolvimento Científico e Tecnológico (CNPq) pelo apoio financeiro, a Universidade Estadual Paulista (UNESP) junto ao Programa de Pós-Graduação em Biotecnologia, Laboratório de Biohidrometalurgia e a empresa Itatijuca Biotech.

\section{REFERÊNCIAS}

I Caheté FLS. A extração de ouro na Amazônia e suas implicações para o meio ambiente. Belém: Universidade Federal do Pará; 1995.

2 Marsden JO, House Cl. The chemistry of gold extraction. 2nd ed. Littleton: Society for Mining, Metallurgy, and Exploration; 2006.

3 Ubaldini S, Veglio F, Beolchini F, Toro L, Abbruzzese C. Gold recovery from a refractory pyrrhotite ore by biooxidation. International Journal of Mineral Processing. 2000;60:247-262.

4 Ubaldini S, Veglio F, Toro L, Abbruzzese C. Technical Note - Combined bio-hydrometallurgy process for gold recoverey from refractory stibnite. Minerals Engineering. 2000; 13:164I-1646.

5 Rees KL, Van Deventer JSJ. The role of metal cyanide species in leaching gold from a copper concentrate. Minerals Engineering. 1999; 12:877-892.

6 Ubaldini S, Veglio F, Toro L, Abbruzzese C. Biooxidation of arsenopyrite to improve gold cyanidation: study of some parameters and comparison with grinding. International Journal of Mineral Processing. 1997;52:65-80.

7 Attia YA, El-zeki M. Bioleaching of gold pyrite tailings with adapted bacteria. Hydrometallurgy. 1989;22:29I-300.

8 Boon M, Hansford GS, Heijnen JJ. The role of bacterial ferrous iron oxidation in the biooxidation of pyrite. In: Jerez CA, Vargas T, Toledo H, Wiertz JV, editores. Biohydrometallurgical processing. Santiago: University of Chile Press; 1995. p. I53-163. vol. I

9 Karimi GR, Rowson NA, Hewitt CJ. Bioleaching of copper via iron oxidation from chalcopyrite at elevated temperatures. Food and Bioproducts Processing. 2010;88:21-25.

10 Márquez M, Gaspar J, Bessler KE, Magela G. Process mineralogy of bacterial oxidized gold ore in São Bento Mine (Brasil). Hydrometallurgy. 2006;83: I I4-I23.

I I Garcia O Jr. Isolation and purification of Thiobacillus ferrooxidans and Thiobacillus thiooxidans from some coal and uranium mines of Brazil. Revista de Microbiologia. 1991;22:1-6.

12 Garcia O Jr. Estudos da biolixiviação de minérios de urânio por Thiobacillus ferrooxidans [tese de doutorado]. Campinas: Universidade Estadual de Campinas; 1989.

13 Tuovinen O, Kelly D. Biology of Thiobacillus ferrooxidans in relation to microbiological leaching of sulfide ores. Zeitschrift für Allgemeine Mikrobiologie. 1972;12(4):31I.

14 Silverman M, Lundgren D. Studies on the chemoautotrophic iron bacterium ferrobacillus ferrooxidans na improved medium and a harvesting procedure for securing high cell yields. Journal of Bacteriology. 1959;77(5):642-647.

15 Pinheiro AC. Instrução de uso para estudos de cianetação: IT 2000-005-00 - Instrução de trabalho elaborada para o CETEM/MCT. Rio de Janeiro: Coordenação de Metalurgia Extrativa - CME; 2000. 8 p. vol. I.

16 Vogel Al. Colorimetria e espectrofotometria. In: Basset Denney e Jeffery Mendham. Análise inorgânica quantitativa. 4. ed. Rio de Janeiro: Guanabara; 198I. p. 552-553.

17 Góes MAC, Luz AB, Possa MV. Amostragem. In: Luz AB, Sampaio JA, França SCA. Tratamento de minérios. 5. ed. Rio de Janeiro: CETEM/MCT; 2010. p. 19-42.

18 Bevilaqua D, Diez-Perez I, Fugivara CS, Sanz F, Garcia O Jr, Benedetti AV. Characterization of Bornite $\left(\mathrm{Cu}_{5} \mathrm{FeS}_{4}\right)$ electrodes in the presence of the bacterium Acidithiobacillus ferrooxidans. Journal of the Brazilian Chemical Society. 2003; 14:637-644. 
Grangeiro et al.

19 Bevilaqua D, Diez-Perez I, Fugivara CS, Sanz F, Garcia O Jr, Benedetti AV. Oxidative dissolution of chalcopyrite by Acidithiobacillus ferrooxidans analyzed by electrochemical impedance spectroscopy and atomic force microscopy. Bioelectrochemistry. 2004;64:79-84.

20 Santos ALA. Efeito do potencial de óxido-redução na biolixiviação da calcopirita [dissertação de mestrado]. Araraquara: Universidade Estadual Paulista; 2014.

2I Nemati M, Harrison STL, Hansford GS, Webb C. Biological oxidation of ferrous sulphate by Thiobacillus ferrooxidans: a review on the kinetic aspects. Biochemical Engineering Journal. 1998; I: I 7 I-190.

22 Leduc LG, Ferroni GD. The chemolithotrophic bacterium Thiobacillus ferrooxidans. FEMS Microbiology Reviews. 1994; |4(2): 103-120.

23 Holt JG. Bergey's manual of determinative bacteriology. 9th ed. Baltimore: Williams \& Wilkins; 1994. p. 436.

24 Bosecker K. Bioleaching: metal solubilization by microorganisms. FEMS Microbiology Reviews. 1997;20:59I-604.

25 Chan LC, Gu XY, Wong JWC. Comparison of bioleaching of heavy metals from sewage sludge using iron- and sulfuroxidizing bacteria. Advances in Environmental Research. 2003;7:603-607.

26 Davis PW, Solomon EP, Berg LR. The world of biology. Philadelphia: Saunders College Publishing; 1990. p. 928.

$27 \mathrm{Li} \mathrm{Y,} \mathrm{Kawashima} \mathrm{N,} \mathrm{Li} \mathrm{J,} \mathrm{Chandra} \mathrm{AP,} \mathrm{Gerson} \mathrm{AR.} \mathrm{A} \mathrm{review} \mathrm{of} \mathrm{the} \mathrm{structure,} \mathrm{and} \mathrm{fundamental} \mathrm{mechanisms} \mathrm{and}$ kinetics of the leaching of chalcopyrite. Advances in Colloid and Interface Science. 2013; 197:I-32.

28 Curreli L, Loi G, Peretti R, Rossi G, Trois P, Zucca A. Gold recovery enhancement from complex sulphide ores through combined bioleaching and cyanidation. Minerals Engineering. 1997; I0(6):567-576.

Recebido em: 17 Fev. 2016

Aceito em: 13 Out. 2016 